\title{
Nephrolithiasis among male patients with newly diagnosed gout
}

\author{
KS Wan *, CK Liu, MC Ko, WK Lee, CS Huang
}

\section{A B S T R A C T}

Introduction: An elevated serum urate level is recognised as a cause of gouty arthritis and uric acid stone. The level of serum uric acid that accelerates kidney stone formation, however, has not yet been clarified. This study aimed to find out if a high serum urate level is associated with nephrolithiasis.

Methods: Patients were recruited from the rheumatology clinic of Taipei City Hospital (Renai and Zhongxing branches) in Taiwan from March 2015 to February 2016. A total of 120 Chinese male patients with newly diagnosed gout and serum urate concentration of $>7 \mathrm{mg} / \mathrm{dL}$ and no history of kidney stones were divided into two groups according to their serum urate level: $<10 \mathrm{mg} / \mathrm{dL}$ (group $1, \mathrm{n}=80$ ) and $\geq 10 \mathrm{mg} / \mathrm{dL}$ (group $2, \mathrm{n}=40$ ). The mean body mass index, blood urea nitrogen level, creatinine level, urinary $\mathrm{pH}$, and kidney ultrasonography were compared between the two groups.

Results: There were no significant differences in blood urea nitrogen or creatinine level between the two groups. The urine $\mathrm{pH}$ in both groups was formation was detected via ultrasonography in 6.3\% $(5 / 80)$ and $82.5 \%(33 / 40)$ of patients in groups 1 and 2 , respectively $(\mathrm{P}<0.05)$.

Conclusion: A serum urate level of $\geq 10 \mathrm{mg} / \mathrm{dL}$ may precipitate nephrolithiasis. Further studies are warranted to substantiate the relationship between serum urate level and kidney stone formation.

\section{Hong Kong Med J 2016;22:534-7}

DOI: 10.12809/hkmj154694

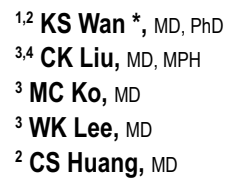

1 Department of Immunology and Rheumatology, Taipei City HospitalZhongxing Branch, Taiwan

${ }^{2}$ Department of Pediatrics, Taipei City Hospital-Renai Branch, Taiwan

3 Department of Urology, Taipei City Hospital-Zhongxing Branch, Taiwan

${ }^{4} \mathrm{Fu}$ Jen Catholic University School of Medicine, Taiwan

* Corresponding author: gwan1998@gmail.com

New knowledge added by this study

- Hyperuricaemia is a risk factor for renal stone formation, which is associated with a substantially higher prevalence of nephrolithiasis on ultrasonography.

- Patients with gouty arthritis and serum urate level of $\geq 10 \mathrm{mg} / \mathrm{dL}$ should be advised to have renal ultrasonography.

\section{Introduction}

Over the past century, kidney stones have become increasingly prevalent, particularly in more developed countries. The incidence of urolithiasis in a given population is dependent on the geographic area, racial distribution, socio-economic status, and dietary habits. ${ }^{1}$ In general, patients with a history of gout are at greater risk of forming uric acid stones, as are patients with obesity, diabetes, or complete metabolic syndrome. ${ }^{2}$ Moreover, elevated serum urate levels are known to lead to gouty arthritis, tophi formation, and uric acid kidney stones. ${ }^{3}$ The incidence of uric acid stones varies between countries and accounts for $5 \%$ to $40 \%$ of all urinary calculi. ${ }^{4}$ Certain risk factors may be involved in the pathogenesis of uric acid nephrolithiasis, including low urinary volume and persistently low urinary $\mathrm{pH}$.
Calcium oxalate stones may form in some patients with gouty diathesis due to increased urinary excretion of calcium and reduced excretion of citrate. In addition, relative hypercalciuria in gouty diathesis with calcium oxalate stones may be due to intestinal hyperabsorption of calcium. ${ }^{6}$ Most urinary uric acid calculi are not pure in composition and complex urates, sodium, potassium, and calcium have been found together in various proportions. ${ }^{7}$ An analysis of stones in gout patients in Japan showed that the incidence of common calcium salt stones was over $60 \%$, while that of uric acid stones was only $30 \%{ }^{8}$ This implies that the disruption of uric acid metabolism promotes not only uric acid stones, but also calcium salt stones. Therefore, a high serum urate level might be associated with nephrolithiasis and this provided the rationale for this study. 


\section{Methods}

Overall, 120 male gouty arthritis patients with newly diagnosed gout and serum urate concentration of $>7$ $\mathrm{mg} / \mathrm{dL}$, and without previous kidney stone disease were allocated to one of the two groups according to their serum uric acid level: $<10 \mathrm{mg} / \mathrm{dL}$ (group 1, $\mathrm{n}=80$ ) and $\geq 10 \mathrm{mg} / \mathrm{dL}$ (group $2, \mathrm{n}=40$ ). Patients were recruited from the rheumatology clinic of Taipei City Hospital (Renai and Zhongxing branches), a tertiary community hospital in Taiwan, from March 2015 to February 2016. They had been newly diagnosed with gout but had no clinical suggestions of renal stone disease. The exclusion criteria included previously treated gouty arthritis and current prescription of urate reabsorption inhibitors. The patient's age, duration of gout arthritis, presence of tophi, body mass index (BMI), blood urea nitrogen (BUN), creatinine, urinary $\mathrm{pH}$, and kidney ultrasonography were all measured and analysed. This study has been approved by the hospital's Institutional Review Board with informed consent waived.

Results for continuous variables were given as means \pm standard deviations. Student's $t$ test was used to compare the physical characteristics that were continuous in nature among the different subject groups and the Chi squared test was used to compare the difference in the stone detection rate between the two groups. A P value of $<0.05$ was regarded as statistically significant for two-sided tests. The Statistical Package for the Social Sciences (Windows version 12.0; SPSS Inc, Chicago [IL], US) was used for all statistical analyses.

\section{Results}

The mean age of the two study groups was similar (40 years). Family history of gout was present in $67.5 \%$ and $90 \%$ of groups 1 and 2 , respectively. The time elapsed since onset of gout was less than 4 years in both groups. Tophaceous gout was found in $8.8 \%$ in group 1 and $10.0 \%$ in group 2 . The prevalence of

\section{初診痛風的男性患者的腎結石 \\ 溫港生、劉志光、柯明中、李文凱、黃哲聖}

引言: 血清尿酸水平偏高是痛風性關節炎和尿酸石的已知原因。血清 尿酸水平上升可加速腎結石形成, 惟兩者關係仍有待驗證。本研究旨 在找出高血清尿酸水平與腎結石形成是否有關。

方法：研究對象為2015年3月至2016年2月期間到台灣臺北市立聯合 醫院（仁愛院區和中興院區）風濕病門診的病人。共有 120 名初診痛 風的男性華籍患者, 無腎結石病史, 血清尿酸水平均高於 $7 \mathrm{mg} / \mathrm{dL}$ 。 按血清尿酸水平把病人分為兩組: 甲組的血清尿酸水平少於 $10 \mathrm{mg} / \mathrm{dL}$ ( 80 人) ）乙組則有 $10 \mathrm{mg} / \mathrm{dL}$ 或以上（40人）。比較兩組 病人的平均身體質量指數、血尿素氮水平、肌酐水平、尿 $\mathrm{pH}$ 值和腎臟 超聲檢查結果。

結果：兩組之間的血尿素氮水平和肌酐水平無顯著差異, 尿 $\mathrm{pH}$ 值相 若且未達統計顯著水平。通過超聲檢測發現甲組和乙組分別有 $6.3 \%$ （5/80）和 $82.5 \% （ 33 / 40 ）$ 的病人有腎結石（ $\mathrm{P}<0.05 ） 。$

結論：10 mg/dL或以上的血清尿酸水平可能誘發腎結石形成, 但須進 一步研究來證實血清尿酸水平與腎結石形成的關係。

patients with a BMI of $\geq 30 \mathrm{~kg} / \mathrm{m}^{2}$ was not statistically significant between the two groups. Only $6 \%$ of group 2 patients with kidney stones had a BMI of $>95$ th percentile. In most cases, urinary $\mathrm{pH}$ was less than 5.5 in both groups and there were no abnormal changes to BUN or creatinine levels. Interestingly, the prevalence of kidney stones detected by ultrasonography was $6.3 \%$ in group 1 and $82.5 \%$ in group $2(\mathrm{P}<0.05)$. The sensitivity and specificity of high serum urate level $(>10 \mathrm{mg} / \mathrm{dL})$ in predicting kidney stones was $87 \%$ and $91 \%$, respectively (Table).

\section{Discussion}

Gout is a common metabolic disorder characterised by chronic hyperuricaemia, and serum urate level of $>6.8 \mathrm{mg} / \mathrm{dL}$ that exceeds the physiological threshold

TABLE. Risk factors of male gout patients with and without nephrolithiasis*

\begin{tabular}{|c|c|c|c|}
\hline Risk factor & $\begin{array}{l}\text { Group } 1(\mathrm{n}=80) \text {, serum } \\
\text { urate level }<10 \mathrm{mg} / \mathrm{dL}\end{array}$ & $\begin{array}{l}\text { Group } 2(n=40) \text {, serum } \\
\text { urate level } \geq 10 \mathrm{mg} / \mathrm{dL}\end{array}$ & $P$ value \\
\hline Age (years) & $40 \pm 5$ & $40 \pm 7$ & 0.061 \\
\hline Time elapsed since onset of gout (years) & $<4$ & $<4$ & 0.312 \\
\hline Tophaceous gout & $7(8.8)$ & $4(10.0)$ & 0.112 \\
\hline BMI $(\geq 30$ kg/m²) & 6 & 4 & 0.081 \\
\hline BUN (10-20 mg/dL) & $13.41 \pm 2.68$ & $13.31 \pm 2.52$ & 0.754 \\
\hline Creatinine (0.6-1.2 mg/dL) & $1.13 \pm 0.24$ & $1.32 \pm 1.11$ & 0.175 \\
\hline Urinary $\mathrm{pH}$ & $5.48 \pm 0.12$ & $5.39 \pm 0.14$ & 0.072 \\
\hline Ultrasonography & $5(6.3)$ & $33(82.5)$ & $<0.05$ \\
\hline
\end{tabular}

Abbreviations: $\mathrm{BMI}=$ body mass index; $\mathrm{BUN}=$ blood urea nitrogen

* Data are shown as mean \pm standard deviation or No. (\%) of patients, unless otherwise stated 
of saturation. Urolithiasis is one of the well-known complications of gout. We hypothesise that serum urate level can be used as a predictive marker for urolithiasis. Uric acid, a weak organic acid, has very low $\mathrm{pH}$-dependent solubility in aqueous solution. Approximately $70 \%$ of urate elimination occurs in urine, and the kidney plays a dominant role in determining plasma level. ${ }^{9}$ A serum urate level of $>7 \mathrm{mg} / \mathrm{dL}$ is recognised as leading to gouty arthritis and uric acid stone formation. Moreover, recent epidemiological studies have identified serum urate elevation as an independent risk factor for chronic kidney disease, cardiovascular disease, and hypertension. ${ }^{3}$ Impaired renal uric acid excretion is the major mechanism of hyperuricaemia in patients with primary gout. ${ }^{10}$ The molecular mechanisms of renal urate transport are still incompletely understood. Urate transporter 1 is an organic anion transporter with highly specific urate transport activity, exchanging this anion with others including most of the endogenous organic anions and drug anions that are known to affect renal uric acid transport. ${ }^{10,11}$

Uric acid stones account for $10 \%$ of all kidney stones and are the second most common cause of urinary stones after calcium oxalate and calcium phosphate. The most important risk factor for uric acid crystallisation and stone formation is a low urine $\mathrm{pH}(<5.5)$ rather than an increased urinary uric acid excretion. ${ }^{12}$ The proportion of uric acid stones varies between countries and accounts for $5 \%$ to $40 \%$ of all urinary calculi. ${ }^{4}$ Uric acid homeostasis is determined by the balance between its production, intestinal secretion, and renal excretion. The kidney is an important regulator of circulating uric acid levels by reabsorbing about $90 \%$ of filtered urate and being responsible for $60 \%$ to $70 \%$ of total body uric acid factor underpinning hyperuricaemia and gout. ${ }^{13}$ Pure uric acid stones are radiolucent but well visualised on renal ultrasound or non-contrast helical computed tomographic scanning; the latter is especially good for detection of stones which are $<5 \mathrm{~mm}$ in size. ${ }^{14}$ Nonetheless the reason why most patients with gout present with acidic urine, even though only $20 \%$ have uric acid stones, remains unclear. In a US study, the prevalence of kidney stone disease was almost two-fold higher in men with a history of gout than in those without (15\% vs $8 \%) .{ }^{15}$ Higher adiposity and weight gain are strong risk factors for gout in men, while weight loss is protective. ${ }^{15}$ An analysis by Shimizu ${ }^{8}$ of stones in gout patients revealed that the proportion of common calcium salt stones was over $60 \%$, while that of uric acid stones was only about $30 \%$. Overweight/obesity and older age associated with low urine $\mathrm{pH}$ were the principal characteristics of 'pure' uric acid stone formers. Impaired urate excretion associated with increased serum uric acid is also another characteristic of uric acid stone formers and resembles patients with primary gout. Patients with pure calcium oxalate stones were younger; they had a low proportion of obese subjects and higher urinary calcium. ${ }^{16}$

Conventionally, BMI was stratified as normal $\left(<25 \mathrm{~kg} / \mathrm{m}^{2}\right)$, overweight $\left(25-29.9 \mathrm{~kg} / \mathrm{m}^{2}\right)$, or obese $\left(\geq 30 \mathrm{~kg} / \mathrm{m}^{2}\right)$. In males, the proportion of uric acid stones gradually increased with BMI, from $7.1 \%$ in normal BMI to $28.7 \%$ in obese subjects. ${ }^{17}$ The same was true in females, with the proportion of uric acid stones rising from $6.1 \%$ in normal BMI to $17.1 \%$ in obese subjects. ${ }^{17}$ Studies found that BMI is associated with an increased risk of kidney stone disease, but with a BMI of $>30 \mathrm{~kg} / \mathrm{m}^{2}$, further increases do not appear to significantly increase the risk of stone disease. ${ }^{17,18}$ An independent association between kidney stone disease and gout strongly suggests that they share common underlying pathophysiological mechanisms. ${ }^{19}$

Three major conditions control the potential for uric acid stone formation: the quantity of uric acid, the volume of urine as it affects the urinary concentration of uric acid, and the urinary $\mathrm{pH} .{ }^{20}$ Two major abnormalities have been suggested to explain overly acidic urine: increased net acid excretion and impaired buffering caused by defective urinary ammonium excretion, with the combination resulting in abnormally acidic urine. ${ }^{21}$ Urinary alkalisation, which involves maintaining a continuously high urinary $\mathrm{pH}(\mathrm{pH}$ 6-6.5), is considered by some or many to be the treatment of choice for uric acid stone dissolution and prevention. ${ }^{20}$ In general, gout is caused by the deposition of monosodium urate crystals in tissue that provokes a local inflammatory reaction. The formation of monosodium urate crystals is facilitated by hyperuricaemia. In a study by Sakhaee and Maalouf, ${ }^{21}$ being overweight and of older age were associated with low urine $\mathrm{pH}$ and one of the principal characteristics of pure uric acid stone formation. Impaired urate excretion associated with increased serum uric acid was another characteristic of uric acid stone formation that resembles patients with primary gout.

The limitations of this current study included the lack of measurement of uric acid concentration of urine in the participants, no further computed tomographic scanning for kidney stones, no analysis of stone composition, and limited representativeness of the study subjects. For example, there were only 10 obese patients $\left(\mathrm{BMI} \geq 30 \mathrm{~kg} / \mathrm{m}^{2}\right.$ ) in the analysis. In this study, hyperuricaemia was a risk factor for kidney stone formation. Patients with serum urate level of $>10 \mathrm{mg} / \mathrm{dL}$ should undergo ultrasound examination to look for any nephrolithiasis.

\section{Declaration}

All authors have disclosed no conflicts of interest. 


\section{References}

1. López M, Hoppe B. History, epidemiology and regional diversities of urolithiasis. Pediatr Nephrol 2010;25:49-59.

2. Liebman SE, Taylor JG, Bushinsky DA. Uric acid nephrolithiasis. Curr Rheumatol Rep 2007;9:251-7.

3. Edwards NL. The role of hyperuricemia and gout in kidney and cardiovascular disease. Cleve Clin J Med 2008;75 Suppl 5:S13-6.

4. Shekarriz B, Stoller ML. Uric acid nephrolithiasis: current concepts and controversies. J Urol 2002;168:1307-14.

5. Ngo TC, Assimos DG. Uric acid nephrolithiasis: recent progress and future directions. Rev Urol 2007;9:17-27.

6. Pak CY, Moe OW, Sakhaee K, Peterson RD, Poindexter JR. Physicochemical metabolic characteristics for calcium oxalate stone formation in patients with gouty diathesis. J Urol 2005;173:1606-9.

7. Bellanato J, Cifuentes JL, Salvador E, Medina JA. Urates in uric acid renal calculi. Int J Urol 2009;16:318-21; discussion 322.

8. Shimizu T. Urolithiasis and nephropathy complicated with gout [in Japanese]. Nihon Rinsho 2008;66:717-22.

9. Marangella $M$. Uric acid elimination in the urine. Pathophysiological implications. Contrib Nephrol 2005; 147:132-48.

10. Taniquchi A, Kamatani N. Control of renal uric acid excretion and gout. Curr Opin Rheumatol 2008;20:192-7.

11. Yamauchi T, Ueda T. Primary hyperuricemia due to decreased renal uric acid excretion [in Japanese]. Nihon Rinsho 2008;66:679-81.

12. Ferrari P, Bonny O. Diagnosis and prevention of uric acid stones [in German]. Ther Umsch 2004;61:571-4.

13. Bobulescu IA, Moe OW. Renal transport of uric acid: evolving concepts and uncertainties. Adv Chronic Kidney Dis 2012;19:358-71.

14. Wiederkehr MR, Moe OW. Uric acid nephrolithiasis: a systemic metabolic disorder. Clin Rev Bone Miner Metab 2011;9:207-17.

15. Choi HK. Atkinson K, Karison EW, Curhan G. Obesity, weight change, hypertension, diuretic use, and risk of gout in men: the health professionals follow-up study. Arch Intern Med 2005;165:742-8.

16. Negri AL, Spivacow R, Del Valle E, et al. Clinical and biochemical profile of patients with "pure" uric acid nephrolithiasis compared with "pure" calcium oxalate stone formers. Urol Res 2007;35:247-51.

17. Daudon M, Lacour B, Jungers P. Influence of body size on urinary stone composition in men and women. Urol Res 2006;34:193-9.

18. Semins MJ, Shore AD, Makary MA, Magnuson T, Johns R, Matlaga BR. The association of increasing body mass index and kidney stone disease. J Urol 2010;183:571-5.

19. Kramer HM, Curhan G. The association between gout and nephrolithiasis: the National Health and Nutrition Examination Survey III, 1988-1994. Am J Kidney Dis 2002;40:37-42.

20. Cicerello E, Merlo F, Maccatrozzo L. Urinary alkalization for the treatment of uric acid nephrolithiasis. Arch Ital Urol Androl 2010;82:145-8.

21. Sakhaee K, Maalouf NM. Metabolic syndrome and uric acid nephrolithiasis. Semin Nephrol 2008;28:174-80. 